\title{
Effects of extracellular polymeric substances on silver nanoparticle bioaccumulation and toxicity to Triticum aestivum L.
}

\author{
Qing-Long Fu ${ }^{\mathrm{a}, 1}$, Chun-Jie Zhong ${ }^{\mathrm{b}, 1}$, Ting Qing ${ }^{\mathrm{b}}$, Zi-Yan Du ${ }^{\mathrm{b}}$, Cheng-Cheng- Li ${ }^{\mathrm{b}, \mathrm{c}, \mathrm{d},{ }^{*} \text {, }}$ \\ Jun-Jie Fei ${ }^{\mathrm{d}}$, Willie J.G.M. Peijnenburg ${ }^{\mathrm{e}, \mathrm{f}}$ \\ a School of Environmental Studies, China University of Geosciences, Wuhan, 430074, PR China \\ ${ }^{\mathrm{b}}$ Department of Environmental Science and Engineering, College of Environment and Resources, Xiangtan University, Xiangtan, 411105, PR China \\ ${ }^{\mathrm{c}}$ National Innovation Institute of Defense Technology, Chinese Academy of Military Sciences, Beijing, 100071, PR China \\ ${ }^{\mathrm{d}}$ Key Laboratory of Environmentally Friendly Chemistry and Applications of Ministry of Education, College of Chemistry, Xiangtan University, Xiangtan, 411105, PR \\ China \\ ${ }^{\mathrm{e}}$ Institute of Environmental Sciences (CML), Leiden University, P.O. Box 9518, 2300, RA, Leiden, the Netherlands \\ ${ }^{\mathrm{f}}$ National Institute of Public Health and the Environment (RIVM), P.O. Box 1, Bilthoven, the Netherlands
}

\section{A R T I C L E I N F O}

Handling Editor: Patryk Oleszczuk

\section{Keywords:}

Extracellular polymeric substances (EPS)

Silver nanoparticles

Phytotoxicity

Rhizosphere

\begin{abstract}
A B S T R A C T
The potential effects of extracellular polymeric substances (EPS) on the behavior and toxicity of silver nanoparticle (Ag-NPs) and silver sulfide nanoparticle $\left(\mathrm{Ag}_{2} \mathrm{~S}-\mathrm{NPs}\right)$ remains ambiguous. The interaction of EPS from Bacillus subtilis with $\mathrm{Ag}_{2} \mathrm{~S}-\mathrm{NPs}$, metallic $\mathrm{Ag}-\mathrm{NPs}$, or ionic $\mathrm{Ag}$, and the associated plant safety had been examined in this study. The biological impacts of $\mathrm{Ag}$-NPs and $\mathrm{Ag}_{2} \mathrm{~S}$-NPs were $\mathrm{Ag}$ form-dependent and highly influenced by microbial EPS. Compared with metallic Ag-NPs, $\mathrm{Ag}_{2} \mathrm{~S}$-NPs exert inert biological impacts, as revealed by 3.44 times lower Ag bioaccumulation in wheat (Triticum aestivum $\mathrm{L}$.) seedlings and nearly reduce plant biomass when wheat was subjected to $1.0 \mathrm{mg}-\mathrm{Ag} \mathrm{L}^{-1}$ of $\mathrm{Ag}$-NPs and $\mathrm{Ag}_{2} \mathrm{~S}$-NPs with the transfer factors of 151.56-930.87 vs. 12.52-131.81, respectively. These observations were coincident with the low dissolved $\mathrm{Ag}\left([\mathrm{Ag}]_{\text {diss }}\right)$ in the $\mathrm{Ag}_{2} \mathrm{~S}$ NPs treatment than the Ag-NPs treatment (114.0 vs. $0.0791, \mu \mathrm{g} \mathrm{L}^{-1}$ ). Compared with the enhanced toxicity of $\mathrm{Ag}_{2} \mathrm{~S}$-NPs to wheat, Bacillus subtilis EPS significantly alleviate the phytotoxicity of Ag-NPs, as revealed by the relative root elongation (7.15-45.40\% decrease vs. $2.39-11.75 \%$ increase), and malondialdehyde (1.47-83.22\% increase vs. $8.57-25.25 \%$ decrease) and $\mathrm{H}_{2} \mathrm{O}_{2}$ (11.27-71.78\% increase vs. $5.16-36.67 \%$ decrease) contents. These constrasting plant responses of $B$. subtilis EPS are mainly caused by their complexation property with toxic $\mathrm{Ag}^{+}$and nutrient elements for wheat stressed by Ag-NPs and $\mathrm{Ag}_{2} \mathrm{~S}-\mathrm{NPs}$, respectively. Our findings highlight the importance of rhizospheric EPS in affecting the biogeochemistry and ecotoxicity of metal nanoparticles including $\mathrm{Ag}$-NPs and $\mathrm{Ag}_{2} \mathrm{~S}$-NPs in agricultural systems.
\end{abstract}

\section{Introduction}

Over the few decades, silver nanoparticles (Ag-NPs) are commonly used in medical devices, coatings, textiles, food packaging, and cosmetics due to their strong antimicrobial properties (Ahamed et al., 2010; Keller et al., 2013; Wu et al., 2020). The subsequently released Ag-NPs and or ionic silver $\left(\mathrm{Ag}^{+}\right)$in surrounding environments is of increasing risk concerns (Dobias and Bernier-Latmani, 2013; Pourzahedi et al., 2017; Prajitha et al., 2019). Additionally, the phytotoxicity of Ag-NPs is also related to the aging process of Ag-NPs. Indeed, Ag-NPs are generally introduced into environments through the practices of wastewater effluent and land-application of biosolids and will be mainly transformed to chronic $\mathrm{Ag}_{2} \mathrm{~S}$ nanoparticles ( $\mathrm{Ag}_{2} \mathrm{~S}-\mathrm{NPs}$ ) (Pradas del Real et al., 2016; Wang et al., 2016). Due to the low solubility and reactivity, $\mathrm{Ag}_{2} \mathrm{~S}$-NPs are considered to be less toxic than $\mathrm{Ag}^{+}$and $\mathrm{Ag}$-NPs (Liu et al., 2018). However, $\mathrm{Ag}_{2} \mathrm{~S}$-NPs could be directly taken up by plant roots and subsequently transferred to leaves without substantial transformation or dissolution (Wang et al., 2015b, 2017). Furthermore, more $\mathrm{Ag}^{+}$is expected due to the hypochlorite oxidative or $\mathrm{Fe}^{3+}$-mediated dissolution of $\mathrm{Ag}_{2} \mathrm{~S}$-NPs in some natural environments, such as in surface water or aqueous systems with environmental levels of $\mathrm{Fe}^{3+}$ under the sunlight condition (Li et al., 2016b, 2017). These findings have demonstrated

\footnotetext{
* Corresponding author. National Innovation Institute of Defense Technology, Chinese Academy of Military Sciences, Beijing, 100071, PR China.

E-mail addresses: fuqinglong@cug.edu.cn (Q.-L. Fu), ccli@xtu.edu.cn (C.-C. Li).

1 These authors contributed equally to this work.
} 
that the stability and bioavailability of the $\mathrm{Ag}_{2} \mathrm{~S}$-NPs are governed by environmental conditions, suggesting the possible misestimation of eco-environmental safety of $\mathrm{Ag}_{2} \mathrm{~S}$-NPs in previous studies. Compared with numerous toxicity studies of Ag-NPs, no attempts has been performed to compare the influence of biogenic organic matter such as extracellular polymeric substances (EPS) on the transformation behavior of $\mathrm{Ag}$-NPs and $\mathrm{Ag}_{2} \mathrm{~S}$-NPs. Therefore, elucidating the effects of these nanoparticles in intricate ecosystems will shed lights on the potential impact of $\mathrm{Ag}_{2} \mathrm{~S}$-NPs and $\mathrm{Ag}$-NPs in the environment and the phytotoxicity mechanisms.

Due to the inevitable reaction with $\mathrm{Ag}_{2} \mathrm{~S}$-NPs and Ag-NPs, natural organic matter (NOM) will greatly affect their transport, stabilization, dissolution, bioaccumulation, bioavailability and phytotoxicity in the environments (Xu et al., 2019). EPS, the complex macromolecular substances from various microbial activities, are mainly consist of polysaccharides, proteins, nucleic acids (Huangfu et al., 2019). Because of the high content of functional groups, EPS can effectively bind heavy metals and prevent their toxic metals from contacting directly with the cells (Sheng et al., 2010; Kang et al., 2014). Additionally, the phenol groups and hemiacetal reducing terminal in polysaccharides may be related to the reducing ability of EPS towards high-oxidation-state metals including $\mathrm{Ag}^{+}$(Cao et al., 2011; Zhang et al., 2016). The tolerance of bacterial or algal cells to heavy metals and nanoparticles is also enhanced by the EPS. For instance, EPS from Escherichia coli are capable of increasing its survival ratio by 4.3 and 1.6 times for $\mathrm{Cu}^{2+}$ and $\mathrm{Cd}^{2+}$, respectively, due to the complexation of metal-EPS, which decreased the cellular absorbability of metals (Shou et al., 2018). EPS from a green alga (Chlorella pyrenoidosa) could facilitate the $\mathrm{TiO}_{2}$ nanoparticles aggregation and sedimentation, limiting algal cell internalization of $\mathrm{TiO}_{2}$ nanoparticles (Gao et al., 2018). However, information regarding the comparative effect of EPS on the behavior and toxicity of Ag-NPs and $\mathrm{Ag}_{2} \mathrm{~S}$-NPs to plants remains limited. Furthermore, the phytotoxicity of Ag-NPs to wheat Triticum aestivum $\mathrm{L}$. and the relevant $\mathrm{Ag}^{+}$dissolution were clearly mitigated by EPS from a representative Gram-negative bacterium, Pseudomonas putida (Li et al., 2016a). On the contrary, dissolved organic matter (DOM) had been reported to causes more copper ions released from copper nanoparticles and might pose a higher toxicity to organisms (Wang et al., 2015a). These contrasting effects have highlighted the importance of organic composition in regulating the dissolution and toxicity of metal nanoparticles. In addition to cell wall compositions, the chemical compositions and prosperities of bacterial EPS are largely species-dependent, particularly for Gram-negative versus Gram-positive cells. For example, EPS from a Gram-positive bacterium, Bacillus vallismortis sp., were rich in polysaccharides (Li et al., 2020); while EPS from a novel Gram-negative bacterium, Acidithiobacillus $\mathrm{sp}$. Ksh, contained more protein-like substances (Vardanyan et al., 2020). EPS from Bacillus subtilis (Gram-positive) were less aliphatic and hydrophobic than EPS from two Gram-negative bacteria, E. coli and P. putida, respectively (He et al., 2015; Chen et al., 2021). The higher contents of polysaccharides and proteins from $B$. subtilis EPS than $P$. putida EPS provided more binding sites for heavy metals, accounting for the higher decrease percentage of $\mathrm{Cd}$ adsorption on $B$. subtilis cells compared with $P$. putida cells (51.4\% versus 9.7\%) caused by EPS removal (Wei et al., 2011). The important role of EPS in regulating AgNPs phytotoxicy had already been confirmed for Gram-negative P. putida cells by our previous study (Li et al., 2016a), while the role of Gram-positive bacterial EPS toward the phytotoxicy of AgNPs or $\mathrm{Ag}_{2} \mathrm{~S}-\mathrm{NPs}$ is still unclear.

The representative Gram-positive bacterium, B. subtilis, was used to investigate the influence of its EPS on the phytotoxicity and associated mechanisms of $\mathrm{Ag}_{2} \mathrm{~S}-\mathrm{NPs}, \mathrm{Ag}-\mathrm{NPs}$, and $\mathrm{Ag}^{+}$to an important cereal crop, Triticum aestivum L. in this study. B. subtilis is a common plant growthpromoting rhizobacteria, exhibiting protective effects for plants against abiotic and biotic stresses (Bais et al., 2004; Lastochkina et al., 2017). Transmission electron microscope (TEM) and energy-dispersive spectroscopy (EDS) were used to probe visually the formation and element compositions of EPS-nanoparticles complex. The key structural components of EPS involved in their reactions with nanoparticles were characterized by three-dimensional excitation-emission matrix (EEM) fluorescence spectroscopy and Fourier-transform infrared spectroscopy (FTIR).

\section{Materials and methods}

\subsection{Nanoparticles and characterization}

$\mathrm{Ag}_{2} \mathrm{~S}$-NPs were synthesized by the reported method using $\mathrm{AgNO}_{3}$ and elemental sulfur (Wang et al., 2015b). Briefly, $42.0 \mathrm{mg}$ of sulfur was dissolved in $50 \mathrm{~mL}$ warm ethanol $\left(\sim 60^{\circ} \mathrm{C}\right)$ by bath sonication (KQ-3200, Kunshan, China), then added dropsies to $500 \mathrm{~mL} \mathrm{AgNO}_{3}$ solution (1 mM) containing $500 \mathrm{mg}$ polyvinylpyrrolidone under magnetic stirring. The reaction was performing for $5 \mathrm{~h}$ at $60{ }^{\circ} \mathrm{C}$ under dark. $\mathrm{Ag}_{2} \mathrm{~S}$-NPs were concentrated by centrifugation $(10,000 \mathrm{~g}, 30 \mathrm{~min})$ and purified with deionized (DI) water for 3 times. Then $\mathrm{Ag}_{2} \mathrm{~S}$-NPs stock was suspended in ultrapure water and stored at $4{ }^{\circ} \mathrm{C}$ under dark prior to use. PVP-coated silver nanoparticles (Ag-NPs) were purchased from XFNANO Materials Technology Ltd. (Nanjing, China).

The morphology and elemental composition of the $\mathrm{Ag}_{2} \mathrm{~S}$-NPs and $\mathrm{Ag}$ NPs were examined with TEM-EDS (Hitachi HT-7700, Japan). Hydrodynamic size and zeta $(\zeta)$ potential of Ag-NPs $\left(1 \mathrm{mg} \mathrm{L}^{-1}, \mathrm{pH} 6.0 \pm 0.1\right)$ and $\mathrm{Ag}_{2} \mathrm{~S}$-NPs (300 mg L ${ }^{-1}$, pH $6.0 \pm 0.1$ ) were characterized using a zetasizer (Nano ZS, Zen 3700, Malvern Instruments, UK). All nanoparticle stocks were ultrasonicated for $10 \mathrm{~min}$ prior to use to achieve a uniform particle distribution.

Dissolved Ag, defined as the concentration of ionic Ag dissolved from Ag-NPs and $\mathrm{Ag}_{2} \mathrm{~S}$-NPs in nutrient medium, was quantified by inductively coupled plasma mass spectrometry (ICP-MS, Agilent, 7700x, USA) analysis. Prior to ICP-MS analysis, $4 \mathrm{~mL}$ suspension was centrifuged at $5000 \mathrm{~g}$ for $20 \mathrm{~min}$ to removal nanoparticles using Amicon Ultra-4 centrifugal ultrafiltration filter ( $3 \mathrm{kDa}$, Millipore, Billerica, USA), and the filtrate was digested with $\mathrm{HNO}_{3}$ and $\mathrm{H}_{2} \mathrm{O}_{2}$.

\subsection{EPS extraction and characterization}

Bacillus subtilis, a typical soil bacterium isolated from a metalcontaminated municipal waste in Wuhan, China (Fang et al., 2011), was used for EPS extraction with our previous method (Li et al., 2016a). Briefly, $B$. subtilis was inoculated in the Luria broth $\left(10 \mathrm{~g} \mathrm{~L}^{-1}\right.$ tryptone, 5 $\mathrm{g} \mathrm{L}^{-1}$ yeast extract, $5 \mathrm{~g} \mathrm{~L}^{-1} \mathrm{NaCl}$, $\mathrm{pH}$ 7.4) and cultivated on a horizontal vibrator $\left(30^{\circ} \mathrm{C}, 150 \mathrm{rpm}\right)$ for $24 \mathrm{~h}$ to reach the stable growth phase. Cell solution was centrifuged $\left(5000 \mathrm{~g}, 4^{\circ} \mathrm{C}, 10 \mathrm{~min}\right.$ ) to remove bacterial cells, followed by an additional centrifugation $\left(10,000 \mathrm{~g}, 4{ }^{\circ} \mathrm{C}, 20 \mathrm{~min}\right)$ to remove other cell residues. The supernatant was mixed with ice-cold ethanol at a volumetric ratio of $3: 1$ (ethanol: EPS supernatant) for $48 \mathrm{~h}$, and the raw $B$. subtilis EPS were obtained by centrifugation (8000 $\mathrm{g}, 10 \mathrm{~min})$. The pellet was further dialyzed by spectral/Por 7 regenerated cellulose membrane for $3 \mathrm{~d}$ to remove small molecular weight impurities by replacing DI water three times per day. The purified B. subtilis EPS were freeze-dried and stored at $-20^{\circ} \mathrm{C}$ for later experiments.

The total organic carbon (TOC) and zeta potential of B. subtilis EPS were determined by a TOC analyzer (TOC-LCPH, Shimadzu, China) and Zetasizer (Nano ZS, Zen 3700, Malvern Instruments, UK), respectively. Total nitrogen (TN), total phosphorus (TP), polysaccharides and protein contents were measured by the alkaline potassium persulfate ultraviolet spectrophotometric method, molybdenum blue spectrophotometric method (Johnes and Heathwaite, 1992; Li et al., 2016b), phenol-sulfuric acid method and comassie brilliant blue method (Chen et al., 2015), respectively. The nucleic acids content were measured by the diphenylamine colorimetric method with the standard of calf thymus DNA (Jia et al., 2017). 


\subsection{Toxicity assays and Ag uptake experiment}

Root elongation test. The wheat (Triticum aestivum L., Yang line 16) seeds, purchased from Lixiahe Agricultural Research Institute of Jiangsu Province, Yangzhou, China, were sterilized in $0.5 \% \mathrm{NaClO}$ solution for $10 \mathrm{~min}$ and then thoroughly washed for three times with DI water.

To explore the 48-h root elongation toxicity test, sterilized seeds were germinated at $28 \pm 1{ }^{\circ} \mathrm{C}$ on wet filter paper for $48 \mathrm{~h}$ in the dark with $80 \%$ relative humidity. Afterwards, 10 uniform wheat seeding with $1.5 \mathrm{~cm}$ root length were selected and transplanted to a nutrient medium $\left(0.25 \mathrm{mM} \mathrm{KNO}_{3}, 0.25 \mathrm{mM} \mathrm{MgSO}_{4} \cdot 7 \mathrm{H}_{2} \mathrm{O}, 0.25 \mathrm{mM} \mathrm{Ca}(\mathrm{NO})_{3} \cdot 4 \mathrm{H}_{2} \mathrm{O}, 0.08\right.$ $\mathrm{mM} \mathrm{KH} \mathrm{PO}_{4}, 2 \mathrm{mM}$ Morpholineethanesulfonic acid, $\mathrm{pH} 6.0 \pm 0.1$ ) amended with different concentrations of $\mathrm{AgNO}_{3}(0,0.05,0.1,0.25,0.5$ and $1.0 \mathrm{mg} \mathrm{L}^{-1}$ ), Ag-NPs (0, 0.05, 0.2, 0.5, 1.0 and $2.0 \mathrm{mg} \mathrm{L}^{-1}$ ) or $\mathrm{Ag}_{2} \mathrm{~S}$ NPs $\left(0,0.5,1.0,5.0,10.0\right.$ and $\left.15.0 \mathrm{mg} \mathrm{L}^{-1}\right)$. There were four parallel trials for each treatment. After 48-h exposure, two longest roots of each seedling were measured, and a total of 20 measurements from 10 seedlings in each replicate were averaged. To assess the role of $B$. subtilis EPS on the toxicity of Ag, seedlings were exposed to the fixed median effective concentrations ( $\mathrm{EC}_{50}$ ) of $\mathrm{Ag}^{+}, \mathrm{Ag}-\mathrm{NPs}$, and $\mathrm{Ag}_{2} \mathrm{~S}-\mathrm{NPs}$ with a series of concentrations of $B$. subtilis EPS $\left(0,10,20,50\right.$ and $100 \mathrm{mg} \mathrm{L}^{-1}$, based on mass concentration). After harvest, the wheat seedlings were rinsed with L-cysteine (10 mM, pH 8.0) and DI water to remove looselybound $\mathrm{Ag}$ ions or nanoparticles, and then dried and digested with $10 \mathrm{~mL}$ $\mathrm{HNO}_{3}$ and $1 \mathrm{~mL} \mathrm{H} \mathrm{O}_{2}$. Silver contents were determined by ICP-MS.

Malondialdehyde (MDA) analysis. MDA levels in wheat roots were measured by a thiobarbituric acid (TBA) reactive substances assay (Jambunathan, 2010) and assessed as lipid peroxidation. Briefly, frozen tissues were homogenized with $5 \mathrm{~mL}$ phosphate buffer solution $(0.05 \mathrm{M}$ $\mathrm{NaH}_{2} \mathrm{PO}_{4} / \mathrm{Na}_{2} \mathrm{HPO}_{4}$ ) and centrifuged (5000 g, $4{ }^{\circ} \mathrm{C}, 10 \mathrm{~min}$ ). The supernatant was sufficiently mixed with a mixture of trichloroacetic acid (5\%) and TBA $(0.5 \%)$, heated in a water bath at $95{ }^{\circ} \mathrm{C}(10 \mathrm{~min})$, and subjected to UV spectrophotometric analysis at 532 and $600 \mathrm{~nm}$ (Cary 60 UV-Vis spectrophotometer, Agilent Technologies).

Hydrogen peroxide $\left(\mathrm{H}_{2} \mathrm{O}_{2}\right)$ analysis. $\mathrm{H}_{2} \mathrm{O}_{2}$ contents were determined by a public protocol (Li et al., 2020). Briefly, $0.5 \mathrm{~g}$ of fresh roots were homogenized with acetone, centrifuged $\left(5000 \mathrm{~g}, 4^{\circ} \mathrm{C}, 10 \mathrm{~min}\right)$, and added with titanium sulfate and concentrated ammonia hydroxide. After additional centrifugation $(5000 \mathrm{~g}, 10 \mathrm{~min})$, the precipitate (a peroxide-titanium complex) was washed with acetone for three times (to remove plant pigment), dissolved in sulfuric acid and then measured at 415 nm (Cary 60 UV-Vis spectrophotometer, Agilent Technologies, USA).

\subsection{Spectral analysis}

The B. subtilis EPS $\left(1000 \mu \mathrm{g} \mathrm{mL}^{-1}\right)$ sample containing $\mathrm{AgNO}_{3}(0.1 \mathrm{mg}$ $\left.\mathrm{L}^{-1}\right)$, Ag-NPs $\left(0.3 \mathrm{mg} \mathrm{L}^{-1}\right)$ or $\mathrm{Ag}_{2} \mathrm{~S}$-NPs $\left(12 \mathrm{mg} \mathrm{L}^{-1}\right)$ was mixed with cold ethanol ( $1: 3 \mathrm{vol}$ ), respectively. After settling for $48 \mathrm{~h}$ at $4{ }^{\circ} \mathrm{C}$, the precipitate was centrifuged $(10,000 \mathrm{~g}, 20 \mathrm{~min})$. The freeze-dried samples mixed with $\operatorname{KBr}(1: 100, w / w)$ were acquired by FTIR spectrometer (Nicolet 380, Thermo Fisher Scientific Inc., USA) from 400 to $4000 \mathrm{~cm}^{-1}$ with a resolution of $4 \mathrm{~cm}^{-1}$.

The EEM fluorescence spectroscopy was used to characterize the fluorescent EPS components of $B$. subtilis EPS. All samples were measured by a luminescence spectrophotometer (F-7000 FL, Hitachi, Japan) with DI water as the blank. The EEM spectra were recorded at 5 $\mathrm{nm}$ sampling intervals with the excitation wavelength from $200 \mathrm{~nm}$ to $500 \mathrm{~nm}$, and the emission spectrum was scanned from $200 \mathrm{~nm}$ to $500 \mathrm{~nm}$ at a scan rate of $2400 \mathrm{~nm} \mathrm{~min}{ }^{-1}$. Excitation and emission of slits were maintained at $5 \mathrm{~nm}$.

\subsection{Characterization of NPs and EPS reaction}

Nanoparticles and $B$. subtilis EPS suspension samples were captured on carbon formvar copper grids. B. subtilis EPS solutions $\left(1000 \mathrm{mg} \mathrm{L}^{-1}\right)$ containing $100 \mathrm{mg} \mathrm{L}^{-1} \mathrm{Ag}$-NPs or $50 \mathrm{mg} \mathrm{L}^{-1} \mathrm{Ag}_{2} \mathrm{~S}$-NPs were incubated for $48 \mathrm{~h}$ to prepare nanoparticle-EPS complexes. Several drops of nanoparticle-EPS complexes were added to copper grids and held for 15 min for vacuum drying for TEM analysis.

The possible dissolution of nanoparticles caused by EPS was also examined by mixing B. subtilis EPS (0, 10, 20, 50, $\left.100 \mathrm{mg} \mathrm{L}^{-1}\right)$ and AgNPs $\left(2 \mathrm{mg} \mathrm{L}^{-1}\right)$ or $\mathrm{Ag}_{2} \mathrm{~S}$-NPs $\left(15 \mathrm{mg} \mathrm{L}^{-1}\right)$ in the nutrient solutions. After $12 / 24 / 48 \mathrm{~h}$ incubation, $4 \mathrm{~mL}$ suspension was centrifuged at $5000 \mathrm{~g}$ for $20 \mathrm{~min}$ to remove nanoparticles using Amicon Ultra-4 centrifugal ultrafiltration filter (3 kDa, Millipore, Billerica, USA), and the filtrate was digested and quantified dissolved Ag contents by ICP-MS.

\subsection{Data analysis}

The relative root elongation (RRE, \%) and $\mathrm{EC}_{50}$ were calculated and fitted using Eqs. (1) and (2), respectively (Haanstra et al., 1985; Fu et al., 2016, 2018; Li et al., 2016a):

$$
\begin{aligned}
& \operatorname{RRE}(\%)=\frac{R L_{T}-R L_{S}}{R L_{C}-R L_{S}} \times 100 \\
& \operatorname{RRE}(\%)=\frac{100}{1+e^{a \times\left(x-\operatorname{lnEC} C_{50}\right)}}
\end{aligned}
$$

where $\mathrm{RL}_{\mathrm{T}}(\mathrm{cm})$ represented the mean root length $(\mathrm{RL})$ in the presence of toxicants (i.e., $\mathrm{AgNO}_{3}$, $\mathrm{Ag}-\mathrm{NPs}$ or $\mathrm{Ag}_{2} \mathrm{~S}-\mathrm{NPs}$ ), $\mathrm{RL}_{\mathrm{S}}(\mathrm{cm})$ represented $\mathrm{RL}$ at the time of seeding transfer to the exposure medium, and $\mathrm{RL}_{\mathrm{C}}(\mathrm{cm})$ represented RL in the nutrient solutions without toxicants. $a$ is the slope parameter indicating the inhibition ratio, and $x$ is the natural logarithm of the toxicant concentration.

Differences between treatments were determined using one-way ANOVA (SPSS 19.0), followed by a Student-Newman-Keuls (S-N-K) test at a significance of $p<0.05$. Data was present as mean $\pm \mathrm{SD}(n=$ $3-4)$.

\section{Results and discussion}

\subsection{Nanoparticles and EPS characterization}

Both Ag-NPs and $\mathrm{Ag}_{2} \mathrm{~S}$-NPs were in spherical shape with particle sizes of $19.3 \pm 0.5 \mathrm{~nm}, 67.3 \pm 2.2 \mathrm{~nm}$, respectively (Fig. S1). Ag-NPs (1 $\mathrm{mg} \mathrm{L}^{-1}, \mathrm{pH} 6.0 \pm 0.1$ ) and $\mathrm{Ag}_{2} \mathrm{~S}$-NPs $\left(3 \mathrm{mg} \mathrm{L}^{-1}, \mathrm{pH} 6.0 \pm 0.1\right)$ in DI water were homodisperse with an average hydrodynamic size of $96.7 \pm 0.5 \mathrm{~nm}$ and $147 \pm 3.9 \mathrm{~nm}$ (Fig. S1), respectively.

The TOC, TP and TN contents of $B$. subtilis EPS were $387.0 \pm 25.5$, $9.1 \pm 2.7$ and $57.4 \pm 0.4 \mathrm{mg} \mathrm{g}^{-1}$ of, respectively. B. subtilis EPS contained comparable TOC and TN, but significantly less TP than $P$. putida EPS $(p<0.05)$ (Li et al., 2016a), which was consistent with the fact that lipid layers in cell walls of the Gram-negative $P$. putida cells were much thicker than those for the Gram-positive B. subtilis cells. In addition, the purified $B$. subtilis EPS were predominantly composited by proteins and polysaccharides ( $87.3 \pm 8.5,227.2 \pm 8.0 \mathrm{mg} \mathrm{g}^{-1}$, respectively), followed by less content of nucleic acids $\left(13.6 \pm 2.1 \mathrm{mg} \mathrm{g}^{-1}\right)$. Proteins and polysaccharides contents of $B$. subtilis EPS in this study were around half of our previously reported values for P. putida EPS (Li et al., 2016a). Furthermore, B. subtilis EPS and P. putida EPS were reported to have comparative levels of polysaccharides (437.6 versus $532.2 \mathrm{mg} / \mathrm{g}$, respectively), but differ largely in protein contents (249.1 versus 152.2 $\mathrm{mg} \mathrm{g}^{-1}$ protein, respectively) under the same experimental conditions and procedures (He et al., 2015). But, an inverse tendency was also reported for EPS from $B$. subtilis and $P$. putida cultured in the same way with EPS extracted by the cationic exchange resin (Wei et al., 2011). These results demonstrated that the yield and biochemical composition of EPS are not only dependent on bacterial species, but also vary from cultural and extractions. B. subtilis EPS and P. putida EPS might, therefore, affect differently on the transform and phytotoxicity of Ag-NPs and $\mathrm{Ag}_{2} \mathrm{~S}$-NPs. The zeta $(\zeta)$ potential of B. subtilis EPS $\left(1000 \mathrm{mg} \mathrm{L}^{-1}\right)$ 
determined by the dynamic light scattering (DLS) technique was $-17.67 \pm 5.99$ at $\mathrm{pH} 6.0 \pm 0.1$ (Fig. S2), implying the electronegative properties of $B$. subtilis EPS under our experimental conditions.

\subsection{Ag bioaccumulation and phytotoxicity to wheat}

As illustrated in Figs. 1A and S3, the RRE values of the wheat were significantly reduced for the $\mathrm{AgNO}_{3}$ (25.73-89.28\%) and Ag-NPs (13.51-86.92\%) with a dose-dependent effect, but less decreased (6.17-59.86\%) by $\mathrm{Ag}_{2} \mathrm{~S}$-NPs. The variation of fresh biomass was consistent with RRE results. The fresh biomass of the root and shoot treated with to $1.0 \mathrm{mg} \mathrm{L} \mathrm{L}^{-1}$ of $\mathrm{AgNO}_{3}, \mathrm{Ag}-\mathrm{NPs}$ and $\mathrm{Ag}_{2} \mathrm{~S}$-NPs with a reduction of $49.26 \%$ and $48.47 \%, 45.59 \%$ and $39.58 \%, 6.62 \%$ and $-2.66 \%$ compared to the control, respectively (Fig. 1B). At the biochemical level, MDA and $\mathrm{H}_{2} \mathrm{O}_{2}$ contents were used to assess lipid peroxidation levels in wheat roots. Both the MDA and the $\mathrm{H}_{2} \mathrm{O}_{2}$ contents increased significantly relative to the control group after exposure to a series of concentrations of $\mathrm{AgNO}_{3}, \mathrm{Ag}$-NPs and $\mathrm{Ag}_{2} \mathrm{~S}-\mathrm{NPs}$ (Fig. 1C). It should be noted that, at similar silver exposure levels (e.g., $1.0 \mathrm{mg} \mathrm{L}^{-1}$ ), the MDA and the $\mathrm{H}_{2} \mathrm{O}_{2}$ contents of $\mathrm{Ag}_{2} \mathrm{~S}$-NPs exposure were lower than $\mathrm{AgNO}_{3}$ and $\mathrm{Ag}$-NPs treatments, suggesting that $\mathrm{Ag}_{2} \mathrm{~S}$-NPs was less deleterious. These results are consistent with earlier studies and suggesting an $\mathrm{Ag}$ species-dependent and dose-dependent growth inhibition toward wheat seedlings. Although $\mathrm{Ag}_{2} \mathrm{~S}$-NPs is extremely inert and insoluble, exposure to $\mathrm{Ag}_{2} \mathrm{~S}$-NPs could reduce the growth of wheat (Wang et al., 2017), and ionic Ag is more toxic than metallic Ag-NPs (Dimkpa et al., 2013).

The total silver including all $\mathrm{Ag}$ that was associated with the wheat (externalized and internalized) after rinsed with L-cysteine and rewashed with DI water. Significant differences $(p<0.05)$ were observed for $\mathrm{Ag}$ accumulation in wheat roots and shoots exposed to a series of concentrations of $\mathrm{AgNO}_{3}, \mathrm{Ag}-\mathrm{NPs}$ with a concentrationdependent increase. Although the concentration of $\mathrm{Ag}_{2} \mathrm{~S}$-NPs in nutrient solution was 10 -fold higher than that of $\mathrm{AgNO}_{3}$ or $\mathrm{Ag}$-NPs, the concentrations of $\mathrm{Ag}$ in the wheat roots treated with $\mathrm{Ag}_{2} \mathrm{~S}$-NPs were prominently lower $(p<0.05)$ than the other two treatments $(1322.92 \pm$ $64.76,234.23 \pm 54.86$ and $68.18 \pm 16.98 \mu \mathrm{g} \mathrm{g}{ }^{-1}$ (DW) for $1.0 \mu \mathrm{g}-\mathrm{Ag}$ $\mathrm{mL}^{-1}$ of $\mathrm{AgNO}_{3}, \mathrm{Ag}-\mathrm{NPs}$, and $\mathrm{Ag}_{2} \mathrm{~S}$-NPs treatment). Moreover, compared with ionic $\mathrm{Ag}$ or metallic $\mathrm{Ag}$-NPs, $\mathrm{Ag}_{2} \mathrm{~S}$-NPs exert inert biological impacts, as revealed by lower (19.40 or 3.44 times) Ag bioaccumulation in plants at equivalent exposure concentrations $\left(1.0 \mathrm{mg} \mathrm{L}^{-1}\right)$ (Fig. 2). The transport factors (TFs) defined as the ratios of $\mathrm{Ag}$ concentrations in roots/shoots to those in exposure solution was calculated to evaluate the transport potential of $\mathrm{Ag}^{+}, \mathrm{Ag}-\mathrm{NPs}$, and $\mathrm{Ag}_{2} \mathrm{~S}$-NPs from nutrient solutions to plant. The results showed that Ag transport potential depended on both the $\mathrm{Ag}$ species and concentrations. Overall, the TFs for the wheat followed in the order of $\mathrm{AgNO}_{3}>\mathrm{Ag}$-NPs $>\mathrm{Ag}_{2} \mathrm{~S}$-NPs, suggesting an $\mathrm{Ag}$ form-dependent impact on Ag accumulation in wheat (Fig. 2). The TFs values decreased with an increasing exposure concentration, which was in line with other studies (Wu et al., 2020), but there was an exception in the $\mathrm{AgNO}_{3}$ treatment. For $\mathrm{AgNO}_{3}$ treatment, the TFs values increased by nearly $228 \%$ when the exposure concentration increased from 0.25 to $1.0 \mathrm{mg} \mathrm{L}^{-1}$.

\subsection{Ag bioaccumulation and phytotoxicity to wheat affected by EPS}

As shown in Figs. 3A and S4, EPS apparently mitigated the inhibition of root elongation of wheat in $\mathrm{AgNO}_{3}$ treatment group, but only slightly in $\mathrm{Ag}$-NPs group at the $\mathrm{EC}_{50}$ levels of $\mathrm{Ag}^{+}$and $\mathrm{Ag}-\mathrm{NPs}(0.1$ and $0.3 \mu \mathrm{g}$ $\left.\mathrm{mL}^{-1}\right)$. However, in $\mathrm{Ag}_{2} \mathrm{~S}$-NPs treatment at $\mathrm{EC}_{50}$ level $\left(12 \mu \mathrm{g} \mathrm{mL}^{-1}\right)$, the RRE decreased with the increase of EPS concentrations, implying the enhanced toxicity of $\mathrm{Ag}_{2} \mathrm{~S}$-NPs by EPS to wheat. Compared with the root elongation, the biomass of wheat was less affected by EPS (Fig. 3B). Moreover, the RRE was inhibited by the EPS concentration over $50 \mathrm{mg}$ $\mathrm{L}^{-1}$ for both in $\mathrm{AgNO}_{3}$ and Ag-NPs treatments (Fig. 3A). Because NOM can affect the stability and biotransformation of nanoparticles in aqueous environment (Li et al., 2018b), the enhanced effect of EPS on wheat roots growth was probably not caused by its potential role as a growth matrix, but due to the complexation property of EPS with Ag ions or form EPS-NPs complex (Glenn and Klaine, 2013; Li et al., 2018a),

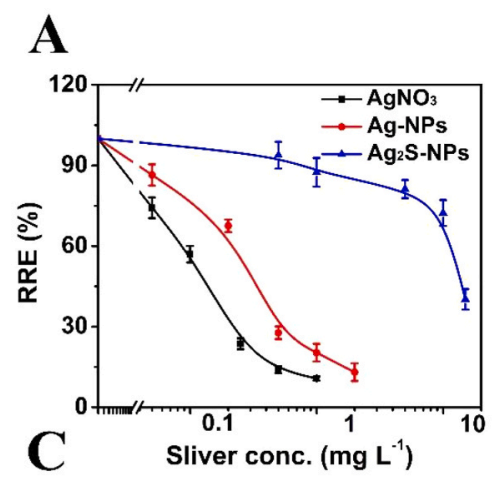

B
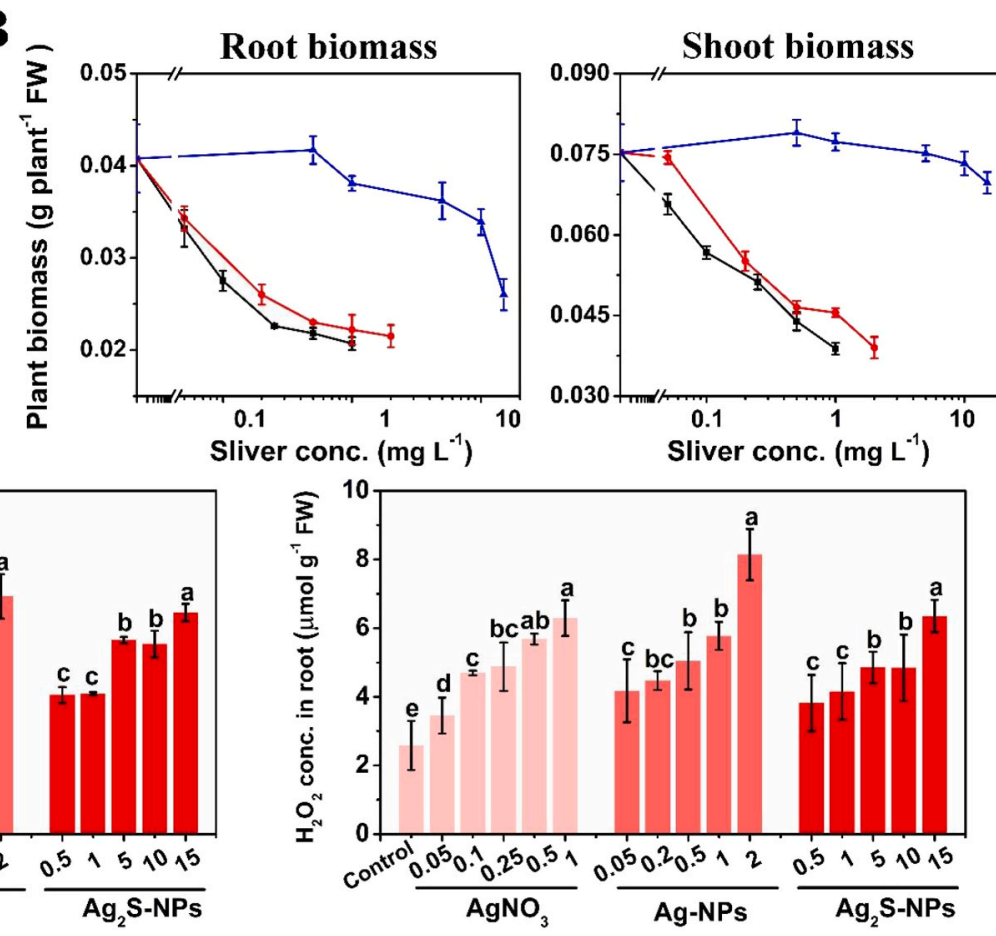

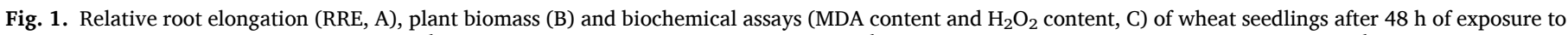

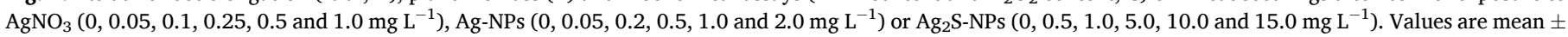
$\mathrm{SD}$ (Four replicates with 10 seedlings per replicate). 


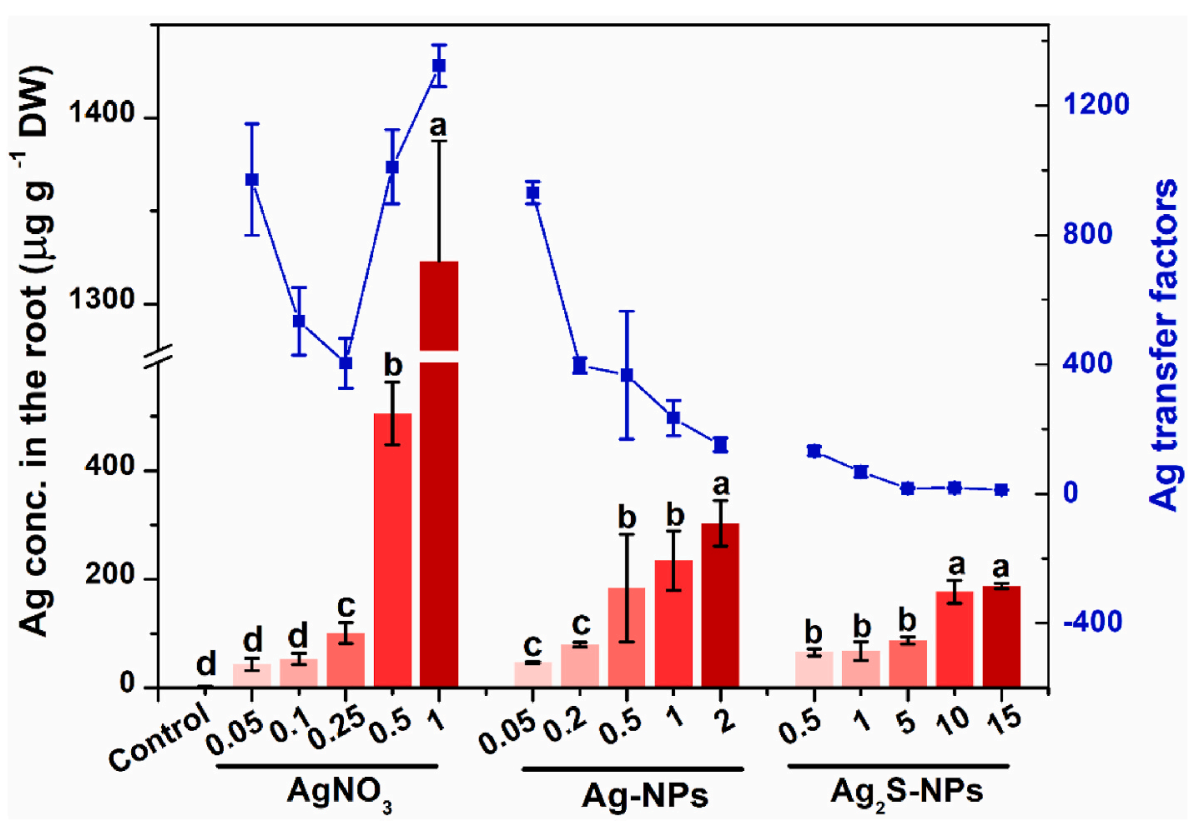

Fig. 2. Ag accumulation in wheat root and the associated $\mathrm{Ag}$ transfer factors (TFs) after $48 \mathrm{~h}$ of exposure to $\mathrm{AgNO}_{3}\left(0,0.05,0.1,0.25,0.5\right.$ and $\left.1.0 \mathrm{mg} \mathrm{L}^{-1}\right), \mathrm{Ag}$ NPs $\left(0,0.05,0.2,0.5,1.0\right.$ and $\left.2.0 \mathrm{mg} \mathrm{L}^{-1}\right)$ or $\mathrm{Ag}_{2} \mathrm{~S}$ NPs $\left(0,0.5,1.0,5.0,10.0\right.$ and $\left.15.0 \mathrm{mg} \mathrm{L}^{-1}\right)$. The TFs are defined as the ratios of $\mathrm{Ag}$ concentrations in roots to those in exposure solution. Values are mean \pm SD (Four replicates with 10 seedlings per replicate). Different letters represent statistical differences among treatments at $p<0.05$.

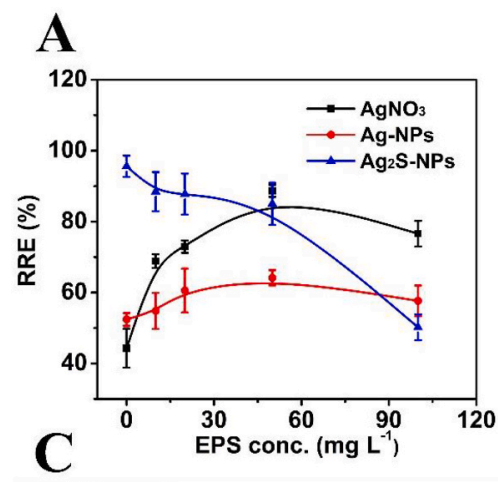

B

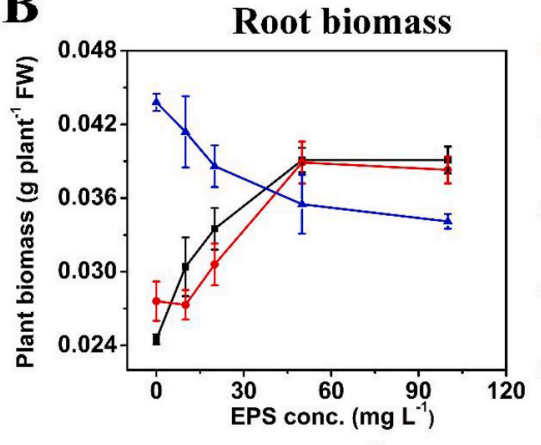

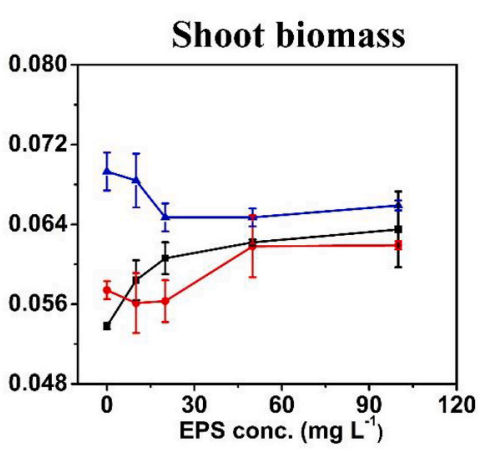
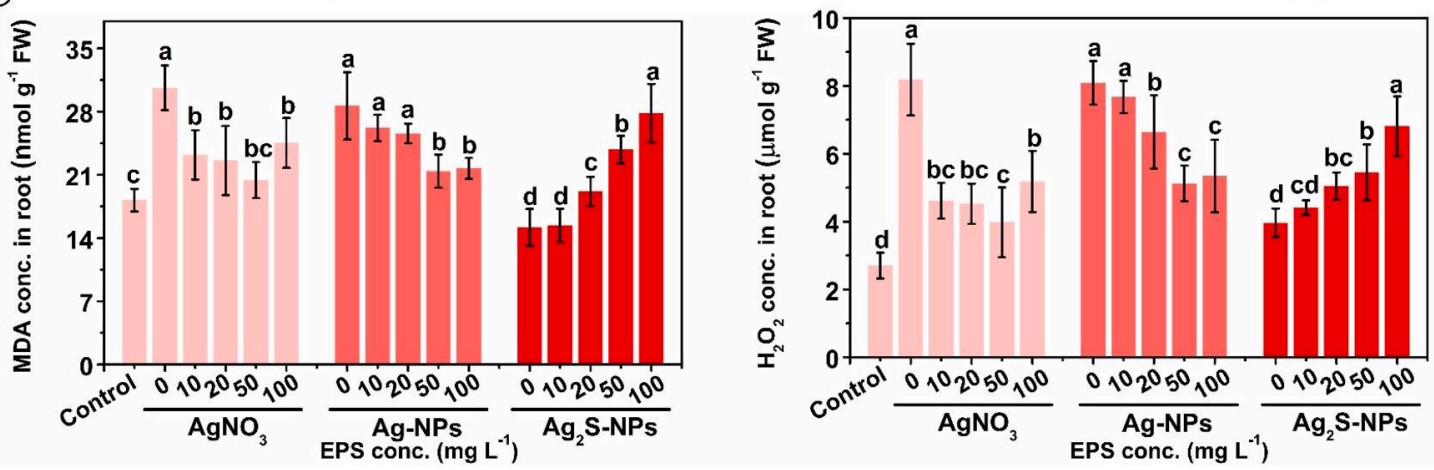

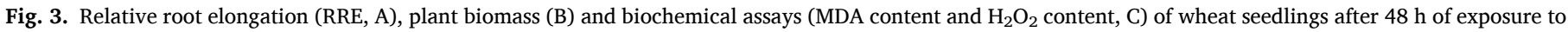

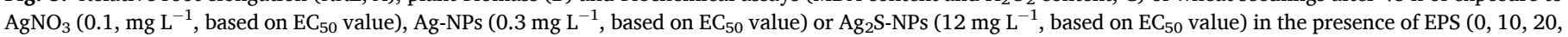
50 and $100 \mathrm{mg} \mathrm{L}^{-1}$ ). Values are mean $\pm \mathrm{SD}$ (Four replicates with 10 seedlings per replicate).

which finally relieved the phytotoxicity of $\mathrm{AgNO}_{3}$ and Ag-NPs.

The oxidative damage of wheat root was quantitatively assessed by MDA and $\mathrm{H}_{2} \mathrm{O}_{2}$ assays (Fig. 3C). MDA contents were significantly decreased upon increasing B. subtilis EPS concentrations for $\mathrm{AgNO}_{3}$ and Ag-NPs groups, but increased slightly by $100 \mathrm{mg} \mathrm{L}^{-1}$ B. subtilis EPS. On the contrary, for $\mathrm{Ag}_{2} \mathrm{~S}-\mathrm{NPs}$ treatment, the MDA content increased with the increasing levels of $B$. subtilis EPS up to $100 \mathrm{mg} \mathrm{L}^{-1}$ (Fig. 3C). The variation tendency of $\mathrm{H}_{2} \mathrm{O}_{2}$ contents was generally consistent with that for MDA content. Similarly, it was also reported that NOM could mitigates the seed germination and root elongation of rice stressed by
$\mathrm{AgNO}_{3} / \mathrm{Ag}$-NPs (Huang et al., 2020). These findings suggest that B. subtilis EPS could alleviate the toxicity of $\mathrm{AgNO}_{3}$ and $\mathrm{Ag}-\mathrm{NPs}$, but aggravate the toxicity of $\mathrm{Ag}_{2} \mathrm{~S}$-NPs.

As shown in Fig. 4 and S5, the concentration of Ag accumulated in roots and shoots after 48-h exposure decreased by $B$. subtilis EPS. For example, the accumulated total $\mathrm{Ag}$ in roots treated with $\mathrm{AgNO}_{3}$, Ag-NPs and $\mathrm{Ag}_{2} \mathrm{~S}$-NPs was decreased by $27.73 \%, 61.15 \%$ and $22.40 \%$, respectively, in the presence of $100 \mathrm{mg} \mathrm{L}^{-1}$ B. subtilis EPS. Similarly, the TFs of Ag decreased with the increase of $B$. subtilis EPS concentration (Fig. 4). The significant decrease of Ag-NPs or $\mathrm{Ag}_{2} \mathrm{~S}$-NPs absorbed on wheat roots 


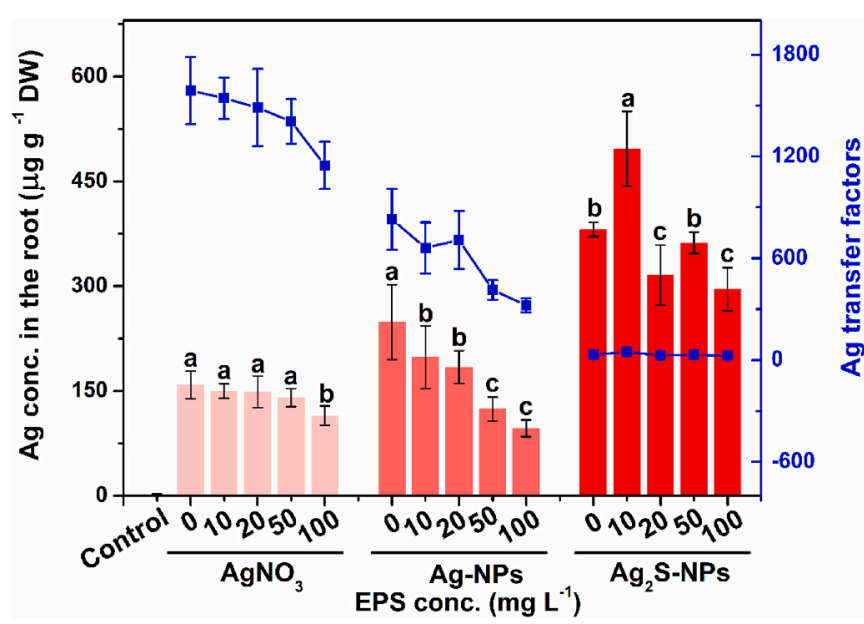

Fig. 4. Ag accumulation in wheat root and the associated $\mathrm{Ag}$ transfer factors (TFs) after $48 \mathrm{~h}$ of exposure to $\mathrm{AgNO}_{3}\left(0.1, \mathrm{mg} \mathrm{L}^{-1}\right), \mathrm{Ag}-\mathrm{NPs}\left(0.3 \mathrm{mg} \mathrm{L}^{-1}\right)$ or $\mathrm{Ag}_{2} \mathrm{~S}$-NPs $\left(12 \mathrm{mg} \mathrm{L}^{-1}\right)$ in the presence of EPS $\left(0,10,20,50\right.$ and $\left.100 \mathrm{mg} \mathrm{L}^{-1}\right)$. The TFs are defined as the ratios of $\mathrm{Ag}$ concentrations in roots to those in exposure solution. Values are mean \pm SD (Four replicates with 10 seedlings per replicate). Different letters represent statistical differences among treatments at $p<0.05$.

by B. subtilis EPS may be resulted from the negative charge feature of B. subtilis EPS, which is involved in the formation of EPS-nanoparticles or EPS-Ag complexes. Free $\mathrm{Ag}^{+}$in $\mathrm{Ag}-\mathrm{NPs}$ solution was reported to be unavailable Ag-NOM complexes (Gunsolus et al., 2015; Li et al., 2018a). It should be notable that $B$. subtilis EPS are capable of reducing $\mathrm{Ag}$ accumulation, but enhancing phytotoxicity of $\mathrm{Ag}_{2} \mathrm{~S}$-NPs to wheat seedlings. These contrasting effects of $B$. subtilis EPS are a result of the metal-binding capacity of $B$. subtilis EPS, which decrease the bioavailability of toxic $\mathrm{Ag}$ ions as well as nutrients (e.g., $\mathrm{Ca}, \mathrm{Mg}$, Fe ions).

The overall tendency of RRE values, MDA and $\mathrm{H}_{2} \mathrm{O}_{2}$ contents, $\mathrm{Ag}$ accumulation affected by $B$. subtilis EPS in this study are consistent with our previous observations for P. putida EPS (Li et al., 2016a). Considering the difference in EPS biochemical compositions between these two studies, this consistent change for B. subtilis EPS and P. putida EPS suggest that the transformation and Ag-NPs toxicity to wheat are insignificantly affected by relative contents of different EPS biochemical compositions. More specifically, proteins play more important roles in altering Ag-NPs dissolution and phytotoxicity and coordinating with

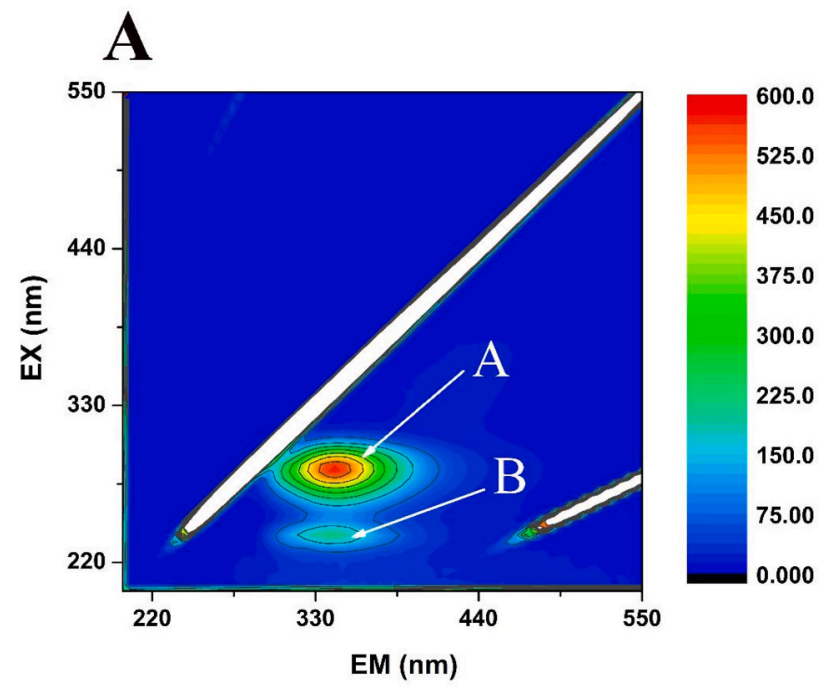

$\mathrm{Ag}^{+}$than polysaccharides because proteins contain more active sites include carboxyl, carbonyl and amide groups, and therefore are more chemically active for metal ions.

\subsection{Interaction mechanism between $\mathrm{Ag}$ and EPS}

As shown in Fig. 5A, two typical peaks of EEM fluorescence spectra were observed in pristine EPS, which were located at Ex/Em (excitation/ emission) wavelengths of 235-280/340 nm and 205-215/225-490 nm, respectively. These peaks indicated that $B$. subtilis EPS were mainly composed of tryptophan-like substances (peak A) and aromatic proteinlike substances (peak B) (Chen et al., 2003; Zhou et al., 2020), implying that protein-like substances were abundant in B. subtilis EPS fluorescent compounds. The FTIR spectra of pristine $B$. subtilis EPS, as well as $\mathrm{AgNO}_{3}$-EPS, Ag-NPs-EPS and $\mathrm{Ag}_{2} \mathrm{~S}$-NPs-EPS incubated for $48 \mathrm{~h}$ were shown in Fig. 5. A similar FTIR spectral profile was observed for pristine EPS, $\mathrm{AgNO}_{3}$-EPS, Ag-NPs-EPS and $\mathrm{Ag}_{2} \mathrm{~S}$-NPs-EPS (Fig. 5B). Peaks for the pristine $B$. subtilis EPS at $3419,1652,1411$, and $1061 \mathrm{~cm}^{-1}$ were assigned to $-\mathrm{OH} /-\mathrm{NH}$ stretching in the hydroxyl group, $\mathrm{C}=\mathrm{O}$ stretching in amide groups of protein-like substances, the symmetric stretching vibration of $\mathrm{C}-\mathrm{O}$ from carboxylic group, and the stretching of $\mathrm{C}-\mathrm{O}-\mathrm{C}$ and C-O in polysaccharides, respectively (Chen et al., 2012; Lai et al., 2018; Zhou et al., 2020). The peak at $2935 \mathrm{~cm}^{-1}$ could be attributed to the asymmetric stretching vibrations of $-\mathrm{CH}_{2}$ of proteins (Fernando et al., 2020). Compared with the pristine B. subtilis EPS, the $\mathrm{AgNO}_{3}$-EPS, Ag-NPs-EPS and $\mathrm{Ag}_{2} \mathrm{~S}$-NPs-EPS complexes show stronger peaks significantly shifted from the 1652 shift to 1645,1646 and $1643 \mathrm{~cm}^{-1}$, respectively. This observation demonstrated the involvement of $\mathrm{C}=\mathrm{O}$ stretching of amide groups in the complexation between EPS and $\mathrm{AgNO}_{3}, \mathrm{Ag}$-NPs, and $\mathrm{Ag}_{2} \mathrm{~S}$-NPs, suggesting the importance of microbial EPS in regulating the transform of Ag-NPs, and $\mathrm{Ag}_{2} \mathrm{~S}$-NPs. In addition, the band of $-\mathrm{OH} /-\mathrm{NH}$ in the hydroxyl group $\left(3419 \mathrm{~cm}^{-1}\right)$, as well as the band corresponding to $\mathrm{C}-\mathrm{O}$ group of polysaccharides $\left(1061 \mathrm{~cm}^{-1}\right)$ became much stronger in this study, suggesting that the hydroxyl and amide groups in the EPS play important roles in the adsorption of B. subtilis EPS onto $\mathrm{Ag}^{+}, \mathrm{Ag}$-NPs, and $\mathrm{Ag}_{2} \mathrm{~S}$-NPs. In general, our data suggested that proteins with abundant functional groups, such as $-\mathrm{NH}$, $-\mathrm{OH}, \mathrm{C}=\mathrm{O}$, and $\mathrm{C}-\mathrm{O}$ the predominant contributors for $\mathrm{Ag}^{+}$-EPS complexation, which in turn support our observation that both $B$. subtilis EPS and $P$. putida EPS exhibit a similar influence the transformation and Ag-NPs toxicity to wheat.

The TEM image results revealed the formation of EPS-nanoparticles complexes (Fig. S6). Compared to the pristine nanoparticles (Fig. S1), a

\section{B}

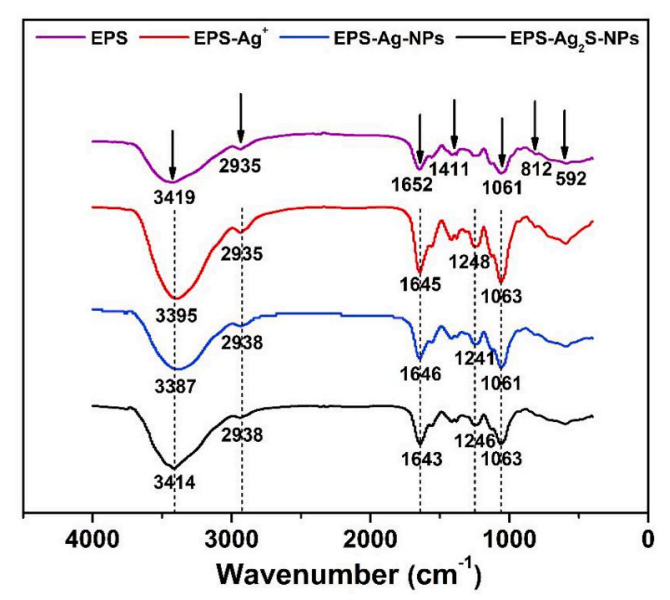

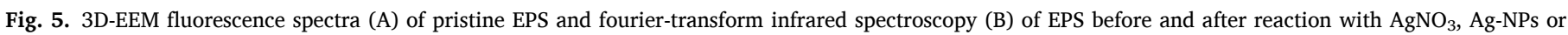
$\mathrm{Ag}_{2} \mathrm{~S}$-NPs. The concentrations of EPS, $\mathrm{AgNO}_{3}, \mathrm{Ag}-\mathrm{NPs}$ and $\mathrm{Ag}_{2} \mathrm{~S}-\mathrm{NPs}$ were $1000 \mathrm{mg} \mathrm{L}^{-1}, 0.1 \mathrm{mg} \mathrm{L}^{-1}, 0.3 \mathrm{mg} \mathrm{L}^{-1}$ and $12 \mathrm{mg} \mathrm{L}-1$, respectively. 
ring of gray material was observed around the nanoparticles surface (Fig. S6) due to the interaction and complexation between B. subtilis EPS and $\mathrm{Ag}-\mathrm{NPs}$ or $\mathrm{Ag}_{2} \mathrm{~S}-\mathrm{NPs}$, which was similar with DOM-Ag-NPs complexes(Ding et al., 2019). EDS results demonstrated the presence of oxygen on EPS-Ag-NPs and EPS- $\mathrm{Ag}_{2} \mathrm{~S}$-NPs complexes surfaces (Figs. S1 and S6), suggesting the adsorption of $B$. subtilis EPS on EPS-Ag-NPs and EPS- $\mathrm{Ag}_{2} \mathrm{~S}$-NPs complexes. B. subtilis EPS were primarily consisted of polysaccharides and proteins as well as some other organic matter (such as fulvic and humic acids) and were negatively charged over the environmental $\mathrm{pH}$ values (3-8, Fig. S2). The EPS-Ag-NPs and EPS- $\mathrm{Ag}_{2} \mathrm{~S}-\mathrm{NPs}$ complexes were also therefore negatively charged, and not easily be accessed to the negatively charged root cell membrane surfaces of plant due to electrostatic repulsion (Wang et al., 2018). The formation EPS-nanoparticles complexes will thus reduce the bioavailability of nanoparticles (Ding et al., 2019), which also support the alleviated phytotoxicity of Ag-NPs in this study (Gao et al., 2012; Huang et al., 2020).

\subsection{Impact of EPS on $\mathrm{Ag}-\mathrm{NPs} / \mathrm{Ag}_{2} \mathrm{~S}-\mathrm{NPs}$ dissolution}

The oxidative dissolution of Ag-NPs in environments is of increasing concerns because the released $\mathrm{Ag}^{+}$is the major contributor to the toxicity of $\mathrm{Ag}$-NPs or $\mathrm{Ag}_{2} \mathrm{~S}$-NPs. In simple solutions without other oxidants or reductants, Ag-NPs dissolution proceeds as in the following stoichiometry (Eq. (3)) (Liu and Hurt, 2010). Moreover, the dissolution of $\mathrm{Ag}_{2} \mathrm{~S}$-NPs may primarily proceed through the following equations (Eq. (4)) in oxidative environments (Li et al., 2017).

$2 \mathrm{Ag}_{(s)}+\frac{1}{2} \mathrm{O}_{2(\mathrm{aq})}+2 \mathrm{H}_{(\mathrm{aq})}^{+} \leftrightarrow 2 \mathrm{Ag}_{(\mathrm{aq})}^{+}+\mathrm{H}_{2} \mathrm{O}_{(\mathrm{l})}$
$\mathrm{Ag}_{2} \mathrm{~S}-\mathrm{NPs}_{(s)} \longrightarrow \mathrm{H}_{2} \mathrm{O}_{2}+\mathrm{OH} \bullet$

As shown in Fig. 6A, the dissolved $\mathrm{Ag}$ concentrations ( $[\mathrm{Ag}]_{\text {diss }}$ ) gradually increased with the increase levels of Ag-NPs in the absence of B. subtilis EPS during $48 \mathrm{~h}$ experimental period. For B. subtilis EPS treatments, the $[\mathrm{Ag}]_{\text {diss }}$ values decreased significantly with increasing concentrations of B. subtilis EPS, which was in line with decreasing level of $[\mathrm{Ag}]_{\text {diss }}$ for Ag-NPs with P. putida EPS (Li et al., 2016a). For example, the $[\mathrm{Ag}]_{\text {diss }}$ reached its maximum $\left(\sim 180.0 \mu \mathrm{g} \mathrm{L}^{-1}\right)$ value after $48-\mathrm{h}$ exposure in the medium solely containing Ag-NPs $\left(2.0 \mathrm{mg} \mathrm{L}^{-1}\right)$. And the $[\mathrm{Ag}]_{\text {diss }}$ value decreased to $65.1 \mu \mathrm{g} \mathrm{L}{ }^{-1}$ for the similar level of Ag-NPs with $100 \mu \mathrm{g} \mathrm{mL}^{-1}$ B. subtilis EPS. Regarding $\mathrm{Ag}_{2} \mathrm{~S}-\mathrm{NPs}$ (Fig. $6 \mathrm{~B}$ ), due to the low solubility of $\mathrm{Ag}_{2} \mathrm{~S}\left(K_{\mathrm{sp}}=6 \times 10^{-51}\right)$ (Lowry et al., 2012; He et al., 2019), the dissolution ratio of $\mathrm{Ag}_{2} \mathrm{~S}$-NPs was closed to $0 \%$ even in the scenario with $15 \mu \mathrm{g} \mathrm{mL}^{-1} \mathrm{Ag}_{2} \mathrm{~S}$-NPs. This observation was coincident with the phenomenon that $\mathrm{Ag}_{2} \mathrm{~S}$-NPs were less toxic than $\mathrm{AgNO}_{3}$ or Ag-NPs even though wheat seedlings were exposed to 15 times higher concentrations of $\mathrm{Ag}_{2} \mathrm{~S}$-NPs than $\mathrm{Ag}-\mathrm{NPs}$ and $\mathrm{AgNO}_{3}$. An insignificant decrease in the $[\mathrm{Ag}]_{\text {diss }}$ value was observed for B. subtilis $\mathrm{EPS}-\mathrm{Ag}_{2} \mathrm{~S}-\mathrm{NPs}$ treatments (Fig. 6B).

Although $B$. subtilis EPS addition reduced insignificantly the dissolution of $\mathrm{Ag}_{2} \mathrm{~S}$-NPs, the dissolution ratio of $\mathrm{Ag}_{2} \mathrm{~S}$-NPs as low as $0 \%$, B. subtilis EPS was thus unlikely to affect the phytotoxicity of $\mathrm{Ag}_{2} \mathrm{~S}$-NPs in terms of $\mathrm{Ag}^{+}$dissolution. Since plants can uptake $\mathrm{Ag}_{2} \mathrm{~S}$-NPs directly without substantial transformation (Wang et al., 2017), the observed phytotoxicity of $\mathrm{Ag}_{2} \mathrm{~S}$-NPs was caused by their nano effects (e.g. reactive oxygen radicals) rather than the released $\mathrm{Ag}^{+}$( $\mathrm{Li}$ et al., 2018b). In this study, it was observed that $B$. subtilis EPS could aggravate $\mathrm{Ag}_{2} \mathrm{~S}-\mathrm{NP}$ toxicity without significantly decreasing the dissolved $\mathrm{Ag}$
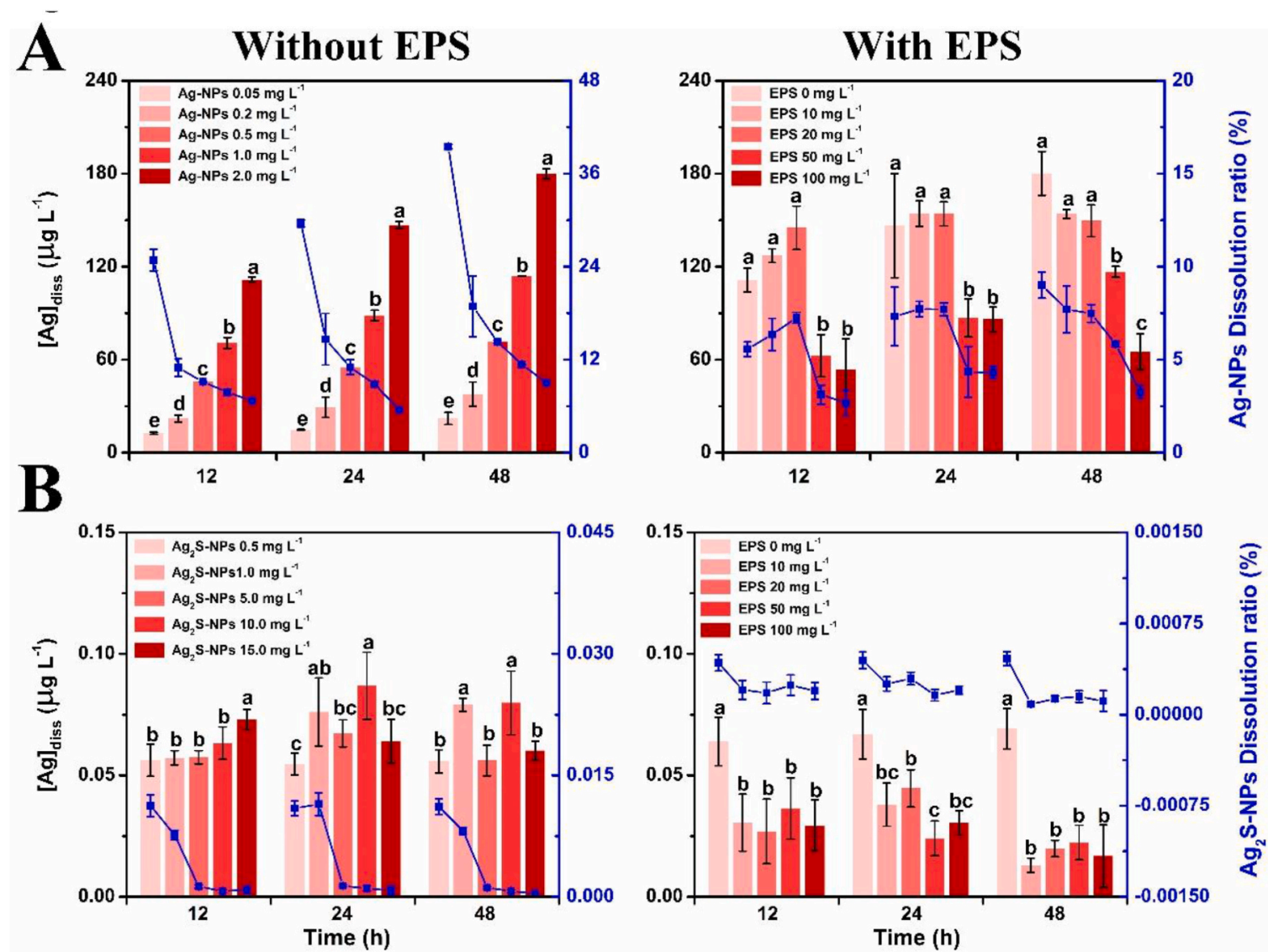

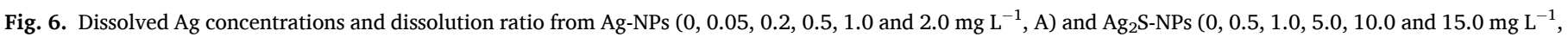

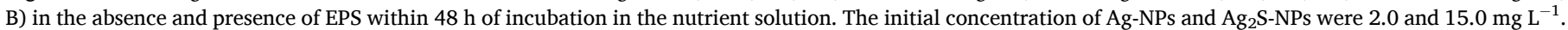
Values are mean \pm SD $(n=3)$. Different letters indicated a significant difference at $p<0.05$. 
concentrations. According to the hard and soft acids and bases (HSAB) theory (Pearson, 1968), proteins in B. subtilis EPS were abundant in soft base function groups, which preferentially coordinated with the soft acid $\mathrm{Ag}^{+}$and less complexed with hard acids, $\mathrm{Fe}^{3+}, \mathrm{Ca}^{2+}$ and $\mathrm{Mg}^{2+}$ in the nutrient media for $\mathrm{AgNO}_{3}$ and Ag-NPs treatments. While, $B$. subtilis EPS will generally bind to $\mathrm{Fe}^{3+}, \mathrm{Ca}^{2+}$ and $\mathrm{Mg}^{2+}$ for the $\mathrm{Ag}_{2} \mathrm{~S}-\mathrm{NPs}$ treatment, where $\mathrm{Ag}^{+}$is far less than $\mathrm{AgNO}_{3}$ and $\mathrm{Ag}$-NPs treatments (Fig. 6), reducing the bioavailability of nutrient elements. Thus, it is reasonably concluded that $B$. subtilis EPS might exacerbate the nano effects of $\mathrm{Ag}_{2} \mathrm{~S}$-NPs or affect the uptake of nutrient elements such as $\mathrm{Fe}^{3+}, \mathrm{Ca}^{2+}$, and $\mathrm{Mg}^{2+}$ by wheat, finally inhibiting plant growth in $\mathrm{Ag}_{2} \mathrm{~S}$-NPs treatment.

\section{Conclusion and environmental significance}

The contrasting effect of microbial EPS on the phytotoxicity and accumulation of $\mathrm{Ag}_{2} \mathrm{~S}$-NPs, metallic Ag-NPs by the crop, Triticum aestivum L. were compared in this study. The $\mathrm{Ag}^{+}$is more toxic than Ag-NPs or $\mathrm{Ag}_{2} \mathrm{~S}$-NPs toward wheat. The $B$. subtilis EPS are capable of alleviating Ag-NPs and $\mathrm{AgNO}_{3}$ phytotoxicity but enhancing the phytotoxicity of $\mathrm{Ag}_{2} \mathrm{~S}$-NPs, which is caused by the interaction between EPS and $\mathrm{Ag}, \mathrm{Ag}$ NPs or $\mathrm{Ag}_{2} \mathrm{~S}$-NPs via amide groups, hydroxyl, carboxyl of protein-like and tryptophan-like substances, forming EPS-nanoparticle complexes. Moreover, dissolution of $\mathrm{Ag}$-NPs and $\mathrm{Ag}_{2} \mathrm{~S}$-NPs is also inhibited by $B$. subtilis EPS. In addition to toxic $\mathrm{Ag}^{+}, B$. subtilis EPS also coordinate with nutrients metals, reduce their bioavailability, hindering the growth of wheat stressed by $\mathrm{Ag}_{2} \mathrm{~S}$-NPs in the presence of B. subtilis EPS.

In comparison with our previous results for P. putida EPS (Li et al., 2016a), similar influences are observed for B. subtilis EPS and P. putida EPS on $\mathrm{Ag}{ }^{+}$dissolution and uptake and phytotoxicity of Ag-NPs to wheat seedlings. Indeed, the major biochemical compositions of B. subtilis EPS and P. putida EPS were comparative (437.6 versus 532.2 $\mathrm{mg}^{-1}$ polysaccharides and 249.1 versus $152.2 \mathrm{mg} \mathrm{g}^{-1}$ protein, respectively) in the same study (He et al., 2015). These similar results suggest that EPS from the representative Gram-positive and Gram-negative, $B$. subtilis and $P$. putida cells, will affect analogously the transform and phytotoxicity of Ag-NPs in the agricultural system. Both $P$. putida and B. subtilis are omnipresent rhizosphere bacteria and are often reorganized as soil dweller or soil colonizer (Earl et al., 2008; Volke et al., 2020). Bacillus and Pseudomonas species can also grow on the root surface, forming biofilm with large yields of EPS on crop roots (Earl et al., 2008; Marvasi et al., 2010; Wheatley and Poole, 2018). The formation of $B$. subtilis biofilm is an important survival strategy for B. subtilis and crops against abiotic and biotic stresses (Bais et al., 2004; Lastochkina et al., 2017). Similarly, $P$. putida is favorable to enhance the phosphorous uptake, growth, and yield of wheat under greenhouse and field conditions (Zabihi et al., 2011), and alleviate biotic stress of Parthenium hysterophorus in wheat (Mishra and Nautiyal, 2012). Because of these results and similar effects of $B$. subtilis EPS and P. putida EPS on dissolution and toxicity of Ag-NPs, the ubiquitous presence of rhizospheric biofilm EPS will reduce $\mathrm{Ag}$-NPs dissolution and $\mathrm{Ag}^{+}$uptake by crops, alleviate Ag-NPs phytotoxicity. Similarly to B. subtilis EPS, $P$. putida EPS is expected to enhance $\mathrm{Ag}_{2} \mathrm{~S}$-NPs toxicity to crops. Findings of this study have highlighted the critical role of EPS in governing the transformation and toxicity of Ag-NPs and $\mathrm{Ag}_{2} \mathrm{~S}$-NPs in rhizosphere, and shed helpful lights on the ecotoxicity and health safety of metal nanoparticles including $\mathrm{Ag}-\mathrm{NPs}$ and $\mathrm{Ag}_{2} \mathrm{~S}$-NPs via food chains in agricultural environments.

\section{Declaration of competing interest}

The authors declare that they have no known competing financial interests or personal relationships that could have appeared to influence the work reported in this paper.

\section{Acknowledgements}

This work was supported by the National Natural Science Foundation of China (No. 41701580), the Natural Science Foundation of Hunan Province (2019JJ50581), and the China Postdoctoral Science Foundation Funded Project (2018M642992). The authors are grateful to anonymous reviewers for their useful comments.

\section{Appendix A. Supplementary data}

Supplementary data to this article can be found online at https://doi. org/10.1016/j.chemosphere.2021.130863.

\section{Credit author statement}

Fu, Q.-L: Data curation, Visualization, Writing - original draft, Writing- Reviewing and Editing; Zhong C.-J.: Conceptualization, Methodology, Investigation, Data curation, Writing - original draft; Qing T.: Investigation; Fei J.-J.: Investigation; Du Z.-Y.: Investigation; Li C.-C.: Conceptualization, Methodology, Supervision, Funding acquisition, Writing - original draft; Fei J.-J.: Investigation; Peijnenburg, W.J.: Writing - original draft.

\section{References}

Ahamed, M., Posgai, R., Gorey, T.J., Nielsen, M., Hussain, S.M., Rowe, J.J., 2010. Silver nanoparticles induced heat shock protein 70, oxidative stress and apoptosis in Drosophila melanogaster. Toxicol. Appl. Pharmacol. 242, 263-269.

Bais, H.P., Fall, R., Vivanco, J.M., 2004. Biocontrol of Bacillus subtilis against infection of Arabidopsis roots by Pseudomonas syringae is facilitated by biofilm formation and surfactin production. Plant Physiol. 134, 307-319.

Cao, B., Ahmed, B., Kennedy, D.W., Wang, Z.M., Shi, L., Marshall, M.J., Fredrickson, J.K., Isern, N.G., Majors, P.D., Beyenal, H., 2011. Contribution of extracellular polymeric substances from Shewanella sp HRCR-1 biofilms to U(VI) immobilization. Environ. Sci. Technol. 45, 5483-5490.

Chen, B., Li, F., Liu, N., Ge, F., Xiao, H.X., Yang, Y.X., 2015. Role of extracellular polymeric substances from Chlorella vulgaris in the removal of ammonium and orthophosphate under the stress of cadmium. Bioresour. Technol. 190, 299-306.

Chen, C.M., Zhang, Q., Yang, M.G., Huang, C.H., Yang, Y.G., Wang, M.Z., 2012. Structural evolution during annealing of thermally reduced graphene nanosheets for application in supercapacitors. Carbon 50, 3572-3584.

Chen, W., Westerhoff, P., Leenheer, J.A., Booksh, K., 2003. Fluorescence excitation emission matrix regional integration to quantify spectra for dissolved organic matter. Environ. Sci. Technol. 37, 5701-5710.

Chen, Y.Q., Wang, M.L., Zhou, X.W., Fu, H.Y., Qu, X.L., Zhu, D.Q., 2021. Sorption fractionation of bacterial extracellular polymeric substances (EPS) on mineral surfaces and associated effects on phenanthrene sorption to EPS-mineral complexes. Chemosphere 263.

Dimkpa, C.O., McLean, J.E., Martineau, N., Britt, D.W., Haverkamp, R., Anderson, A.J., 2013. Silver nanoparticles disrupt wheat (Triticum aestivum L.) growth in a sand matrix. Environ. Sci. Technol. 47, 1082-1090.

Ding, Y.Y., Bai, X., Ye, Z.F., Gong, D.Q., Cao, J.J., Hua, Z.L., 2019. Humic acid regulation of the environmental behavior and phytotoxicity of silver nanoparticles to Lemna minor. Environ.-Sci. Nano 6, 3712-3722.

Dobias, J., Bernier-Latmani, R., 2013. Silver release from silver nanoparticles in natural waters. Environ. Sci. Technol. 47, 4140-4146.

Earl, A.M., Losick, R., Kolter, R., 2008. Ecology and genomics of Bacillus subtilis. Trends Microbiol. 16, 269-275.

Fang, L.C., Wei, X., Cai, P., Huang, Q.Y., Chen, H., Liang, W., Rong, X.M., 2011. Role of extracellular polymeric substances in Cu(II) adsorption on Bacillus subtilis and Pseudomonas putida. Bioresour. Technol. 102, 1137-1141.

Fernando, I., Lu, D., Zhou, Y., 2020. Interactive influence of extracellular polymeric substances (EPS) and electrolytes on the colloidal stability of silver nanoparticles. Environ.-Sci. Nano 7, 186-197.

Fu, Q.L., Blaney, L., Zhou, D.M., 2016. Phytotoxicity and uptake of roxarsone by wheat (Triticum aestivum L.) seedlings. Environ. Pollut. 219, 210-218.

Fu, Q.L., Blaney, L., Zhou, D.M., 2018. Identifying plant stress responses to roxarsone in soybean root exudates: new insights from two-dimensional correlation spectroscopy. J. Agric. Food Chem. 66, 53-62.

Gao, J., Powers, K., Wang, Y., Zhou, H.Y., Roberts, S.M., Moudgil, B.M., Koopman, B., Barber, D.S., 2012. Influence of Suwannee River humic acid on particle properties and toxicity of silver nanoparticles. Chemosphere 89, 96-101.

Gao, X., Zhou, K.J., Zhang, L.Q., Yang, K., Lin, D.H., 2018. Distinct effects of soluble and bound exopolymeric substances on algal bioaccumulation and toxicity of anatase and rutile $\mathrm{TiO}_{2}$ nanoparticles. Environ.-Sci. Nano 5, 720-729.

Glenn, J.B., Klaine, S.J., 2013. Abiotic and biotic factors that influence the bioavailability of gold nanoparticles to aquatic macrophytes. Environ. Sci. Technol. 47, 10223-10230. 
Gunsolus, I.L., Mousavi, M.P.S., Hussein, K., Buhlmann, P., Haynes, C.L., 2015. Effects of humic and fulvic acids on silver nanoparticle stability, dissolution, and toxicity. Environ. Sci. Technol. 49, 8078-8086.

Haanstra, L., Doelman, P., Voshaar, J.H.O., 1985. The use of sigmoidal dose response curves in soil ecotoxicological research. Plant Soil 84, 293-297.

He, D., Garg, S., Wang, Z.M., Li, L.X.Y., Rong, H.Y., Ma, X.M., Li, G.Y., An, T.C., Waite, T. D., 2019. Silver sulfide nanoparticles in aqueous environments: formation, transformation and toxicity. Environ.-Sci. Nano 6, 1674-1687.

He, J.Z., Li, C.C., Wang, D.J., Zhou, D.M., 2015. Biofilms and extracellular polymeric substances mediate the transport of graphene oxide nanoparticles in saturated porous media. J. Hazard Mater. 300, 467-474.

Huang, X.T., Li, Y., Chen, K., Chen, H.Y., Wang, F., Han, X.M., Zhou, B.H., Chen, H.L., Yuan, R.F., 2020. NOM mitigates the phytotoxicity of AgNPs by regulating rice physiology, root cell wall components and root morphology. Environ. Pollut. 260.

Huangfu, X.L., Xu, Y.H., Liu, C.H., He, Q., Ma, J., Ma, C.X., Huang, R.X., 2019. A review on the interactions between engineered nanoparticles with extracellular and intracellular polymeric substances from wastewater treatment aggregates. Chemosphere 219, 766-783.

Jia, F.X., Yang, Q., Liu, X.H., Li, X.Y., Li, B.K., Zhang, L., Peng, Y.Z., 2017. Stratification of extracellular polymeric substances (EPS) for aggregated anammox microorganisms. Environ. Sci. Technol. 51, 3260-3268.

Johnes, P.J., Heathwaite, A.L., 1992. A procedure for the simultaneous determination of total nitrogen and total phosphorus in freshwater samples using persulphate microwave digestion. Water Res. 26, 1281-1287.

Kang, F.X., Alvarez, P.J., Zhu, D.Q., 2014. Microbial extracellular polymeric substances reduce $\mathrm{Ag}^{+}$to silver nanoparticles and antagonize bactericidal activity. Environ. Sci. Technol. 48, 316-322.

Keller, A.A., McFerran, S., Lazareva, A., Suh, S., 2013. Global life cycle releases of engineered nanomaterials. J. Nanoparticle Res. 15.

Lai, C.Y., Dong, Q.Y., Chen, J.X., Zhu, Q.S., Yang, X., Chen, W.D., Zhao, H.P., Zhu, L., 2018. Role of extracellular polymeric substances in a methane based membrane biofilm reactor reducing vanadate. Environ. Sci. Technol. 52, 10680-10688.

Lastochkina, O., Pusenkova, L., Yuldashev, R., Babaev, M., Garipova, S., Blagova, D., Khairullin, R., Aliniaeifard, S., 2017. Effects of Bacillus subtilis on some physiological and biochemical parameters of Triticum aestivum L. (wheat) under salinity. Plant Physiol. Biochem. 121, 80-88.

Li, C.C., Wang, Y.J., Dang, F., Zhou, D.M., 2016a. Mechanistic understanding of reduced AgNP phytotoxicity induced by extracellular polymeric substances. J. Hazard Mater. 308, 21-28.

Li, L.X.Y., Wang, Y.W., Liu, Q., Jiang, G.B., 2016b. Rethinking stability of silver sulfide nanoparticles ( $\mathrm{Ag}_{2} \mathrm{~S}-\mathrm{NPs}$ ) in the aquatic environment: photoinduced transformation of $\mathrm{Ag}_{2} \mathrm{~S}-\mathrm{NPs}$ in the presence of Fe(III). Environ. Sci. Technol. 50, 188-196.

Li, L.X.Y., Xu, Z.L., Wimmer, A., Tian, Q.H., Wang, X.P., 2017. New insights into the stability of silver sulfide nanoparticles in surface water: dissolution through hypochlorite oxidation. Environ. Sci. Technol. 51, 7920-7927.

Li, M., Dang, F., Fu, Q.L., Zhou, D.M., Yin, B., 2018a. Effects of molecular weightfractionated natural organic matter on the phytoavailability of silver nanoparticles. Environ.-Sci. Nano 5, 969-979.

Li, Q.H., Song, W.F., Sun, M.G., Li, J.Y., Yu, Z.F., 2020. Response of Bacillus vallismortis sp. EPS to exogenous sulfur stress/induction and its adsorption performance on $\mathrm{Cu}$ (II). Chemosphere 251.

Li, Y., Chen, H.Y., Wang, F., Zhao, F.R., Han, X.M., Geng, H.H., Gao, L., Chen, H.L., Yuan, R.F., Yao, J., 2018b. Environmental behavior and associated plant accumulation of silver nanoparticles in the presence of dissolved humic and fulvic acid. Environ. Pollut. 243, 1334-1342.

Liu, J.Y., Hurt, R.H., 2010. Ion release kinetics and particle persistence in aqueous nanosilver colloids. Environ. Sci. Technol. 44, 2169-2175.

Liu, S.Q., Wang, C., Hou, J., Wang, P.F., Miao, L.Z., Fan, X.L., You, G.X., Xu, Y., 2018. Effects of $\mathrm{Ag}$ and $\mathrm{Ag}_{2} \mathrm{~S}$ nanoparticles on denitrification in sediments. Water Res. 137, 28-36.

Lowry, G.V., Espinasse, B.P., Badireddy, A.R., Richardson, C.J., Reinsch, B.C., Bryant, L. D., Bone, A.J., Deonarine, A., Chae, S., Therezien, M., Colman, B.P., Hsu-Kim, H., Bernhardt, E.S., Matson, C.W., Wiesner, M.R., 2012. Long-term transformation and fate of manufactured $\mathrm{Ag}$ nanoparticles in a simulated large scale freshwater emergent wetland. Environ. Sci. Technol. 46, 7027-7036.
Marvasi, M., Visscher, P.T., Martinez, L.C., 2010. Exopolymeric substances (EPS) from Bacillus subtilis: polymers and genes encoding their synthesis. FEMS Microbiol. Lett. 313, 1-9.

Mishra, S., Nautiyal, C.S., 2012. Reducing the allelopathic effect of Parthenium hysterophorus L. on wheat (Triticum aestivum L.) by Pseudomonas putida. Plant Growth Regul. 66, 155-165.

Pearson, R.G., 1968. Hard and soft acids and bases, HSAB, part 1: fundamental principles. J. Chem. Educ. 45, 581.

Pourzahedi, L., Vance, M., Eckelman, M.J., 2017. Life cycle assessment and release studies for 15 nanosilver-enabled consumer products: investigating hotspots and patterns of contribution. Environ. Sci. Technol. 51, 7148-7158.

Pradas del Real, A.E., Castillo-Michel, H., Kaegi, R., Sinnet, B., Magnin, V., Findling, N., Villanova, J., Carriere, M., Santaella, C., Fernandez-Martinez, A., Levard, C., Sarret, G., 2016. Fate of Ag-NPs in sewage sludge after application on agricultural soils. Environ. Sci. Technol. 50, 1759-1768.

Prajitha, N., Athira, S.S., Mohanan, P.V., 2019. Bio-interactions and risks of engineered nanoparticles. Environ. Res. 172, 98-108.

Sheng, G.P., Yu, H.Q., Li, X.Y., 2010. Extracellular polymeric substances (EPS) of microbial aggregates in biological wastewater treatment systems: a review. Biotechnol. Adv. 28, 882-894.

Shou, W.J., Kang, F.X., Lu, J.H., 2018. Nature and value of freely dissolved EPS ecosystem services: insight into molecular coupling mechanisms for regulating metal toxicity. Environ. Sci. Technol. 52, 457-466.

Vardanyan, N., Badalyan, H., Markosyan, L., Vardanyan, A., Zhang, R., Sand, W., 2020. Newly isolated Acidithiobacillus sp. Ksh from Kashen copper rre: peculiarities of EPS and colloidal exopolysaccharide. Front. Microbiol. 11 https://doi.org/10.3389/ fmicb.2020.01802.

Volke, D.C., Calero, P., Nikel, P.I., 2020. Pseudomonas putida. Trends Microbiol. 28, $512-513$.

Wang, L.F., Habibul, N., He, D.Q., Li, W.W., Zhang, X., Jiang, H., Yu, H.Q., 2015a. Copper release from copper nanoparticles in the presence of natural organic matter. Water Res. 68, 12-23.

Wang, P., Lombi, E., Sun, S.K., Scheckel, K.G., Malysheva, A., McKenna, B.A., Menzies, N. W., Zhao, F.J., Kopittke, P.M., 2017. Characterizing the uptake, accumulation and toxicity of silver sulfide nanoparticles in plants. Environ.-Sci. Nano 4, 448-460.

Wang, P., Menzies, N.W., Dennis, P.G., Guo, J.H., Forstner, C., Sekine, R., Lombi, E., Kappen, P., Bertsch, P.M., Kopittke, P.M., 2016. Silver nanoparticles entering soils via the wastewater-sludge-soil pathway pose low risk to plants but elevated CI concentrations increase Ag bioavailability. Environ. Sci. Technol. 50, 8274-8281.

Wang, P., Menzies, N.W., Lombi, E., Sekine, R., Blamey, F.P.C., Hernandez-Soriano, M.C., Cheng, M.M., Kappen, P., Peijnenburg, W., Tang, C.X., Kopittke, P.M., 2015b. Silver sulfide nanoparticles ( $\left.\mathrm{Ag}_{2} \mathrm{~S}-\mathrm{NPs}\right)$ are taken up by plants and are phytotoxic. Nanotoxicology 9, 1041-1049.

Wang, Y.M., Zhou, D.M., Yuan, X.Y., Zhang, X.H., Li, Y., 2018. Modeling the interaction and toxicity of $\mathrm{Cu}-\mathrm{Cd}$ mixture to wheat roots affected by humic acids, in terms of cell membrane surface characteristics. Chemosphere 199, 76-83.

Wei, X., Fang, L.C., Cai, P., Huang, Q.Y., Chen, H., Liang, W., Rong, X.M., 2011. Influence of extracellular polymeric substances (EPS) on Cd adsorption by bacteria. Environ. Pollut. 159, 1369-1374.

Wheatley, R.M., Poole, P.S., 2018. Mechanisms of bacterial attachment to roots. FEMS Microbiol. Rev. 42, 448-461.

Wu, J., Wang, G.Y., Vijver, M.G., Bosker, T., Peijnenburg, W., 2020. Foliar versus root exposure of AgNPs to lettuce: phytotoxicity, antioxidant responses and internal translocation. Environ. Pollut. 261.

Xu, S., Chen, X.J., Zhuang, J., 2019. Opposite influences of mineral-associated and dissolved organic matter on the transport of hydroxyapatite nanoparticles through soil and aggregates. Environ. Res. 171, 153-160.

Zabihi, H.R., Savaghebi, G.R., Khavazi, K., Ganjali, A., Miransari, M., 2011. Pseudomonas bacteria and phosphorous fertilization, affecting wheat (Triticum aestivum L.) yield and P uptake under greenhouse and field conditions. Acta Physiol. Plant. 33, 145-152.

Zhang, X., Yang, C.W., Yu, H.Q., Sheng, G.P., 2016. Light-induced reduction of silver ions to silver nanoparticles in aquatic environments by microbial extracellular polymeric substances (EPS). Water Res. 106, 242-248.

Zhou, X.W., Kang, F.X., Qu, X.L., Fu, H.Y., Alvarez, P.J.J., Tao, S., Zhu, D.Q., 2020. Role of extracellular polymeric substances in microbial reduction of arsenate to arsenite by Escherichia coli and Bacillus subtilis. Environ. Sci. Technol. 54, 6185-6193. 